\title{
Im(matter)ial Bodies: \\ A Material and Affective Rethinking of Selfies for Digital Literacy Resources
}

\author{
KATIE WARFIELD \\ Kwantlen Polytechnic University
}

\begin{abstract}
This paper conducts a critical discourse analysis of a recent Canadian adolescent digital literacy resource to show that selfies are treated primarily as discursive objects. This paper suggests that by rethinking selfies as both discursive and important material and affective entanglements - a frequent proposal in recent scholarship on this phenomenon —and by redesigning learning resources accordingly, teachers could encourage students to think in a material, affective, embodied, and more complex way about the experiences of sharing images of bodies online.
\end{abstract}

Keywords

digital literacy, selfies, feminist new materialism, critical discourse analysis, posthumanism

Introduction

Learning outcomes

Students will: (...)

-create a media product (my emphasis)

(MediaSmarts, 2016)

I aim adult content towards Fetlife and a particular Tumblr account, so sexually explicit selfies go there. Twitter and my non-porn Tumblr are both general purpose connection points for me, with a mix of meatspace friends and online relationships. At any given point, it's just a different circle of friends one place or another. So I may post a selfie to both, or just to these friends or those friends.

(Participant, transgender, age 24)

These quotes are paired purposefully to show the gap between Canadian adolescent digital literacy resources and the emerging empirical data on young people's sharing of images of their bodies on social media. The first quote, pulled from a lesson plan called Put Your Best Face Forward by MediaSmarts Canada, aims to teach young people about selfies, or digital self-portraits, often shared via social media platforms like Facebook, Instagram, or Snapchat. MediaSmarts is a Canadian "not-for-profit charitable organization for digital and media literacy. [Their] vision is that children and youth have the critical thinking skills to engage with media as active and informed digital citizens” (MediaSmarts, 2016). I italicize the word product to highlight the treatment of selfies by this teaching resource as a media product - that is, a manufactured object or entity distinct and separahte from the subject, and embodied subjectivity, of the image producer. The second quote above is from some 
of my own empirical work conducted two years ago, with a specific transgender participant discussing their sharing of images of their body on the social media platform Tumblr. They detail the entangled acumen, and situated networked reasoning, involved in handling a selfie that considers platform-based codes of sharing (e.g., "sexually explicit” versus "nonporn”), the importance of space (for expressing sexuality or making connections), and the importance of different online and offline audiences. On the one hand, selfies are discursive objects; on the other hand, they are also materially influenced and affectively laden.

It is my contention that a critical discourse analysis of Put Your Best Face Forward can reveal the treatment of digital images of bodies shared via social media as predominantly representational and presentational. In other words, online images are seen as either products or representations, akin to older representational and mediated images of bodies (such as photos in glossy magazine ads and images of dancers in music videos). Alternatively, they are considered presentational-treated as playful (not serious) performances. In this sense, online self-images are not the real self, but variations of the self-sometimes idealized with the help of editing software and apps and thus deemed possibly problematic in relation to one's body image.

It is not my aim to argue that selfies are not these things. It is, however, my aim to argue that selfies are not only these things. Attending to the composite, layered, and multimodal nature of the technology used to capture selfies-namely, the cellphone-as well as to the networked affect that recent scholars of selfies have detailed as spilling from and through selfie production and sharing (Tiidenberg, 2017; Warfield, 2016a). I suggest that the phenomenon of the selfie be discussed in classrooms as at once representation (a photo), presentation (a performance), and, importantly, materially and affectively entangled.

I begin this paper with reference to recent legal developments and new educational curricula in Canada that point to the importance of understanding, or at minimum of listening to, the material and affective forces at play in the sharing of images of the body on social media. I follow this with a literature review of recent work by selfie scholars that add affect and materiality to existing representational and presentational paradigms. I then use critical discourse analysis (Fairclough, 1989; 2010; Gee, 1999; van Dijk, 2008) to examine the following questions: How are selfies conceived of in Canadian teaching resources concerning digital self-imaging practices? How does a teaching resource construct young people's use of selfies? What genealogically embedded discourses about photography and digital images frame the newer phenomenon of the selfie? These questions are important to ask, since teaching documents perpetuate dominant discourses and ideologies. Returning to recent scholarship on selfies and digital images of the body shared on social media, I then rethink the teaching resource-adding activities that inquire into the material and affective forces at play in selfie production and sharing. I close the paper by reflecting on the essential importance and possible implications of analyzing the material and affective forces that shape classroom discussions about sharing images of the body on social media.

\section{Digital Images of Bodies in Canada: Some Context}

The discourse on selfies, or digital self-imaging — often shared via social mediais fairly well known and permeates mass media, governmental policy and, most recently, educational curricula and resources. This discourse considers selfies to be evidence of vain, 
narcissistic, and often gendered practices of young women (Senft \& Baym, 2015; Warfield, 2015); furthermore, it frequently links to discourses around moral panic, threats of violence, and online bullying (Burns, 2015).

Despite its tendency to be both reductionist and scandalous, there is some material significance to this discourse within the Canadian context. For instance, the much publicized suicides of young Canadians Rehtaeh Parsons (age 17) and Amanda Todd (age 15) came at the end of extended periods of online and offline emotional, psychological, and physical bullying, violence, and sexual humiliation, entangled with the non-consensual distribution of their intimate images. The deaths of these young women led directly to the creation of, and are cited in the preamble to, Bill C-13: "An Act to amend the Criminal Code, the Canada Evidence Act, the Competition Act and the Mutual Legal Assistance in Criminal Matters Act” (Bill C-13, 2014. Colloquially known as an anti-cyberbullying act, this act directly addresses the non-consensual distribution of intimate images online.

In the wake of these events, provincial ministries of education and educational nonprofit media organizations have addressed the complex issues surrounding the online digital imaging of bodies in Canada. Ontario's most recent health and physical education curriculum made national news when it chose to directly address the practice of sexting as well as identity and privacy in relation to online images of bodies. Concurrent with these shifts, MediaSmarts developed a number of learning resources on topics such as online bullying. It is one of these resources, Put Your Best Face Forward-a resource designed to teach young people about selfies — that I address in this paper.

\section{Put Your Best Face Forward Document}

MediaSmarts produced the resource, Put Your Best Face Forward, in 2016, intending it for use by students in grades 7 through 9 . The stated learning outcomes of the resource were fourfold:

1. "to reflect on attitudes towards body image and gender

2. [to] understand the constructed nature of media images

3. [to] learn strategies for managing body image concerns

4. [to] create a media product” (MediaSmarts, 2015)

The learning resource is divided into several sections. The Overview section describes all the stages of the lesson. The Learning Outcomes section states the outcomes just listed above. The Preparation and Materials section lists the equipment needed for the exercises, as well as the videos students are to watch as part of the lesson. The Procedure section describes how the teacher becomes the model for taking a series of selfies while the students help the teacher determine what visual qualities make for the best image. The Selfie-Representation section asks students to 'agree' or 'disagree' with a series of statements, gathered from teens and young adults interviewed by MediaSmarts, "about their experiences with social networking and the Internet” (MediaSmarts, 2015). The Selfie-Representation section also asks a series of reflective questions about what makes good selfies and how selfies may relate to body image. The Filters and Photoshop section asks students about the use of filters in self-imaging practices. The final section, Assessment and Evaluation: Selfie de Milo, asks students to choose a self-portrait from art 
history that is at least 50 years old and, using contemporary filtering programs or apps, edit it to "selfie standards" (MediaSmarts, 2015).

\section{Literature Review}

\section{Selfie Scholarship}

The aforementioned moral panic around selfies meant that early work by selfie academics became a project of critiquing the criticism. Perhaps the best critique of dominant discourse around selfies is found in Theresa Senft and Nancy Baym's introduction to the special section on selfies in the International Journal of Communication. Senft and Baym slate both the unfounded claims of mass media sources and the overall narrow and gendered framing of the popular phenomenon (2015). In that same issue, Anne Burns (2015) addresses the moral panic associated with self-reflection and new technologies. Various articles throughout this publication aim to challenge the negative media coverage and arrest the discursive moral panic surrounding selfies (Miltner \& Baym, 2015). Since then, researchers have looked at selfies in a multitude of ways, defining them as a product and a process (Senft \& Baym, 2015), discursive but also more than discursive. Theorists argue that there are important political implications of proclaiming a clear and fixed definition of selfies, since "when we take a position on research regarding socially mediated bodies, we are both taking a position on social media and we are taking a position on bodies” (Warfield, Cambre, \& Abidin, 2016). Any definition of selfies is also a definition of bodies and how and what they are when they are mediated via social media.

\section{Affect and Materiality in Digital Media and Social Media Studies}

Kindberg, Spasojevic, Fleck, and Sellen (2005) were some of the first to discuss the affective nature of mobile photography when, nearly 15 years ago, they proposed that we were increasingly taking digital images not only for functional purposes but also for affective purposes and outcomes. Affective visuality is not a novel notion; theorists of analogue photography discuss this with regard to the rhetorical impact of photojournalism on the everyday lives of Americans (Sontag, 2008) as well as Roland Barthes's concept of the punctum - those invisible elements of the image that grab us, jar us, and "pierce" the viewing audience (Barthes, 1988). The contemporary use of affect refers to "those registers of experience which cannot be easily seen and which might variously be described as noncognitive, transsubjective, non-conscious, non-representational, intercorporeal, and immaterial" (Blackman, 2013 p. 4). Brian Massumi describes affect as "hope," or "the margin of maneuverability [that determines] where we may be able to go and what we may be able to do" (2015, p. 3). In short, affect is the felt sense of possibility and impossibility that brings the body to move toward or recede from action. Networked Affect, a recent book edited by Ken Hillis, Susanna Paasonen, and Michael Petit (2015), provides a series of case studies in which authors address the issue of affect via social media. As the editors suggest, working with affect is naturally "messy;" however, this messiness is also described by authors as true to the lived experience and thus embraced in their descriptions of the gripping, grabbing, emotional jolts, and bodily pushes and pulls that ensue from encounters with Tumblr (Cho, 2015); GIFs (Ash, 2015); steam punk (Sundén, 2015); avatars (Hillis et al, 2015); and online porn (Maddison, 2015). Jessica Ringrose (2015) draws on Deleuzian 
concepts to describe digital phallic touch, a concept which suggests that images of bodies non-consensually shared online are not simply representations but are also as affectively powerful as a physical touch. Adopting the work of Karen Barad, my own work (Warfield 2016) describes how affect flows deeply through the production of selfies-where selfietakers embody audience reactions, adopt and play with normative tropes of gendered selfpresentation, and cringe at bad selfies while celebrating good ones. Affect and the emotional impact of online activities is an increasingly popular angle for studying the sharing of images of bodies online.

Alongside affect, materiality is gaining increasing importance in studies of online self-imaging. The recently coined term digital materialism (Reichert \& Richterich, 2015) encapsulates the work of theorists interested in pushing beyond representation in digital media studies - that is, beyond screen essentialism (Kirschenbaum, 2008), or the idea that research should focus exclusively on the screen and what happens on it. Instead, digital materialism looks at what happens "behind the screen and the dynamics which happen before and after media's representative societal function" (Reichert \& Richterich, 2015, p. 8). Often drawing on the work of new materialist and posthuman theorists (Barad, 2007; Braidotti, 2013; Deleuze \& Guattari, 1980; Latour, 1979), theorists of digital materialism look at the agency of nonhuman forces in technological encounters, such as the impact of technological elements including interface design (Duguay, 2016) and affordances (McVeigh-Shultz \& Baym, 2015). Dylan Wittkower (2016) also examines the entanglement of materiality and discourses of power in his analysis of discriminatory design, noting the inclusion of dominant social groups and unfair exclusion of others (e.g., the lack of sexuality options beyond binary, hetero, or homosexual on many hookup apps). Similarly, Jill Walker Rettberg (2014) discusses the manner in which technologies of selfimaging historically have been very much entangled with race (e.g., camera color-adjusting cards designed for shades of white skin) and gendered (e.g., self-tracking apps, marketed to mothers, for monitoring babies). In short, while selfies are discursive phenomena, they are also importantly influenced by the agency of nonhuman forces-including technologies of self-imaging and the nonhuman social media platforms on which images are subsequently shared.

\section{A Discourse Analysis of the MediaSmarts Educational Materials}

Discourses are often defined as language in use (Foucault, 1972), wherein power, via language, shapes our sense of what is and what ought to be as a mode of social control and domination. In short, language privileges certain values and peoples over others. As such, critical discourse analysis works well in examining texts that claim to exert an imperative or action over society (e.g., laws, policy, or medical diagnostic texts). For this reason, critical discourse analysis is a fitting methodology for analyzing a teaching resource - in this case, one that was prepared by a large, non-profit media literacy organization for use in Canadian classrooms and family homes. As MediaSmarts notes, their resource intends to "support adults with information and tools so they can help children and teens develop the critical thinking skills they need for interacting with the media they love" (MediaSmarts, 2016). Through this intended shaping of critical thinking skills, MediaSmarts invariably teaches young people how they ought to think about different forms of media, including social media. 


\section{A Discourse Analysis of the MediaSmarts Educational Materials}

I focused on the documents prepared for and referenced in the resource, Put Your Best Face Forward, since this resource directly speaks to sharing images of one's body online. I chose to examine the entire document, which comprised all the sections detailed above. The lesson plan also had external web links, directing students to an exercise called Selfie de Milo as well as an assessment rubric for the Selfie de Milo task. I included all of this material, which comprised ten pages, eight external links, and one video.

I combined detailed methods and query questions from Fairclough (1989) and Gee (1999) to conduct the critical discourse analysis. I drew from Fairclough's Language and Power (1989) to divide the analysis into three stages: 1) systematically describe the text; 2) interpret the relationship between the text and the interaction; and 3) explain the relationship between the interaction and the social context to reveal the dominant discourses that shaped the articulation of the learning resource and the way it was published.

\section{Organization of Findings}

I found Gee's seven building tasks (or, loosely, aspects of the world that discourses build) useful at the macro discursive level of analysis to organize my findings. Gee suggests that discourses first build significance by making certain things significant and, by default, other things insignificant. Discourses also build activities and, subsequently, the normative rules and parameters of those activities. Discourses build identities, or the social roles for people in a given situation. Discourses also built relationships by signalling what sorts of affiliations people are to have with one another in a given context. Discourses further build politics, "or our perspective on social good" (p. 12), and they conceptually build connections by linking certain ideas (or not) to others. Although this analysis revealed discourses affecting identities and relationships, in this paper I focus on the two building tasks, significance and connections, from my findings. There are several thematic subsections under each of these categories.

Finally, I assembled other methods to write up the findings that were common in other critical discourse analysis literature, such as coupling direct quotes from the text of Put Your Best face Forward with my claims (van Dijk, 2008) and linking the various levels of analysis with the earlier literature review and other academic sources.

\section{Building Task \#1: Significance}

Language is used to make things significant and give them meaning and value (Gee, 1999). Language highlights certain aspects of the world, brings them into strategic focus, and shapes how we come to understand them. In the following sections I show how excerpts from Put Your Best Face Forward encourage an understanding of selfies as representations (like photos) and presentations (like an enacted performance).

\section{a) Selfies are representations}

Within the Put your Best Face Forward lesson plan, students are encouraged to make meaning and significance of some of the central concepts of digital self-imaging in specific ways. Students are asked to define the word selfie. As a prompt, the lesson provides a variation of the Oxford English Dictionary definition: A selfie is "a photograph of yourself posted online, usually to a social network such as Instagram or a messaging app such as 
Snapchat." This meaning defines a selfie as primarily a "photograph," and thus representational.

Representationalism has a strong pedigree within studies of photos shared online (Gye, 2009; Kindberg et al., 2005; Okabe \& Ito, 2006; Scifo, 2009; Urry, 2002). The definition by MediaSmarts, however, is limited to defining selfies as a static product-a photo. This meaning is also reinforced, as mentioned in the learning outcomes, when students are asked to produce a "media product."

The definition of selfies as representations continues with the title of the assessment project-a section entitled "Selfie de Milo." This is a playful reference to the many artistic renderings of Venus de Milo — the Roman goddess of beauty, love, desire, and sex. Calling to mind Botticelli's iconic painting of the goddess in an open clamshell, it thereby aligns selfies with the characteristically flat, representational visual media of European Renaissance paintings. The assessment task then asks students to modify a 50-year-old image to "meet selfie standards." The term "standard" fortifies the representational framework, suggesting that the primary purpose of selfie production and distribution is aesthetic - meant to align the aesthetics of one's selfie with the aesthetic standards of other visual media. This assumption is also bolstered one line earlier in the lesson plan, which encourages students to consider "gendered beauty standards" in the production of a selfie. In an earlier exercise, wherein the teacher is to volunteer to be the subject of a classproduced selfie, the lesson instructions provide prompts for educators that again focus on creating an image that conforms or contemplates discursive visual tropes from other representational media, such as magazine ads and commercial photography. These prompts include: "Have a bright light on your face for the 'overexposed' look (washes out lines, blemishes, etc.)” (Mediasmarts, 2016, p.3). Teachers may also deliver the prompts: "Don’t take the photo straight on, turn to the left and right to highlight cheekbones;" "Hold the camera above your face, so that you are looking up at it (...) this makes you look thinner." These prompts structure the significance of the selfie as similar to other visual and mediated representations of the body and then use this definition to encourage discussions of gendered representations of bodies.

The alignment between selfie self-representation and gendered tropes via other representational media is further reinforced in the answer period after this initial exercise. Teachers are directed to ask students: "When you see models in a magazine, do you think about how they might have been Photoshopped?" followed by, "when you see friends' photos, do you think about how they might have been Photoshopped or otherwise manipulated? Does it change how you feel about your own photos?" As mentioned, this line of questioning-focusing attention on filtering and editing photos-encourages students to think about the relationship between mass-mediated images of bodies in relation to visual and discursive similarities within social media self-imaging.

\section{b) Selfies are presentations}

The second meaning of selfies built into Put your Best Face Forward is that they should also be thought of as presentations or performances of the self Reichert \& Richterich, 2015 online.

Within social media studies, theories of performance (Goffman, 1959/2007) and performativity (Butler, 1993) abound. Schwartz and Halegoua (2014), for instance, discuss the concept of the spatial self: "A theoretical framework encapsulating the process of 
online self-presentation based on the display of offline physical activities (p. 1). However, their literature review and the focus of their paper reinforce the concept that identity is real offline and predominantly performed online. Erving Goffman and Judith Butler have emerged as key theorists in understanding the idea of the networked self (Papacharissi, 2010). Although the networked self encourages more imaginative performances of identity online, it is presented often as "idealized performances of who a user is" in real life (Schwartz \& Halegoua, 2014, p. 5).

This discursive, binaried cleaving of the online curated or performed self and the offline real self is evident in the Put you Best Face Forward lesson plan. In the section entitled "Selfies and Self-Representation," students are given a list of statements (from interviews conducted by MediaSmarts with young people) on the topic of social networking and the Internet. Students are asked to state if they agree or disagree with the statements. These statements include: "Kids try to seem better online and happier, and just post everything like that. Some kids try to make them look like everyone's their friend or that their boyfriend's the greatest but in reality they're not." Here again we see the dichotomization of online and offline selves, as well as the alignment of offline experiences with authenticity and those online with idealized performances. Other statements in this section are framed the same way: "There's some people that have different personalities online. They create accounts and they're just on YouTube and they become this character which they are not.” Thus, online platforms are where people cannot be who they really are offline.

An exercise prior to this section discusses the social capital (Bourdieu \& Wacquant, 1992) that flows through perfect (representation) and idealized (presentation) images, suggesting that selfies are primarily products of socioeconomic networked forces. A series of discussion questions after the "Selfies and Self-representation" section includes the following: "How are you 'rewarded' for a good photo online? Are the rewards the same for boys as for girls?" Another asks the flip side: "How are you 'punished' for a bad one? Is it the same for boys and girls?" The terms reward and punishment relate to the entanglement of social capital, identity, and gender policing (Bornstein, 1995). Selfies are not seen so much as communication but rather as a flow and exchange of social capital (Bourdieu, 1979), in which value is awarded when a selfie conforms with aesthetic and gender norms, codes, and scripts. Those images that are not liked, according to this document, are presumed to face hostile or malicious punishment, which also speaks to the document's assumptions about peer relations online. The wording presumes that peers seem to have two default states of emotional response- that is, kind support or malicious penalization. This very much simplifies the complexity of affective experiences and relations online (Boyd, 2014; Livingstone, 2009).

Finally, the wording of awards and punishments disregards the push and pull of power and agency in postmodern theories of subject formation (Althusser, 1970; Foucault 1972). The subtext in Put Your Best Face Forward is that input from peers is undesirable and that feedback relating to subjectivity development is unhelpful, because it either provides a quantified but false sense of support (reward) or it can damage one's sense of self-worth (punishment). In a tacit way, this wording supports either the idea that peers in online spaces are untrustworthy or that subjectivity formation should follow more a humanist tradition-wherein the subject cultivates their sense of self internally and independently, and not in an intersubjective manner with others. 


\section{Building Task \#2: Connections}

Gee (1999) says that we use language to "render certain things connected or relevant (or not) to other things" (p. 12). In other words, we use language to construct both affiliation and relevance as well as disaffiliation and disconnection. Here I am most interested in the connections and disaffiliations that are subtly created through the construction of selfies as representations and presentations in the prior section. These connections and disconnections include the connections of the concepts of curation and inauthenticity, and the separation of those concepts from the real, authentic, and unedited; the disassociation of the concepts and spaces of online and offline; and, lastly, the association of curation and inauthenticity with the online space as well as the association of the real and authentic with that which is offline.

a) Inauthenticity and curation disconnected from authenticity and the real offline

The lesson plan clearly underscores the idea that selfies are predominantly curated, edited, and altered from the original image snapped. However, the wording does not say that it is the image that is altered, but instead associates editing with that of the self or the body. Under the section of the lesson entitled "Filters and Photoshop," educators are asked to have students consider the act of Photoshopping, or editing images. The questions ask students to reflect on the connection between editing images and their own feelings about the person who edited the image. Similar to the "Selfie de Milo" section, one question reads, "when you see models in magazines, do you think about how they might have been Photoshopped? Why or why not?” Another asks, “does it change how you see them if you know they've been Photoshopped?” Here we see the linking of representationalism with presentationalism, wherein the selfie as an edited photo is linked to personal opinions about editing oneself before presenting oneself publicly. This whole section-one of five in the lesson-emphasizes the importance of editing the self as a key component of the selfie phenomenon, whereas research shows that a large number of selfie-takers attempt to minimize editing (Warfield, 2016b) or, in the case of celebrity Instagram influencers, edit images so that the final visual impact of the editing is nearly invisible (Abidin, 2016). All this is to say that, although editing and curating images is often a component of selfies, the effect of the language in this text simplifies the reasons for editing-focusing on the audience's impressions of editing rather than exploring the image-taker's personal reasons for editing.

\section{b) Online disconnected to offline}

Once selfies are established via the language of the text as primarily representational and presentational, the next discursive step is to articulate selfies as either copies of bodies and/or representations that are inauthentic, or different from the real. Working in tandem, the discourse of representationalism severs the image from the body of the producer, and presentationalism reinforces the idea that the embodied self-the offline self-is more authentic than the inauthentic performance of the body online. What we are left with, conceptually and discursively, are the following connections and disconnections: 
Table 1

Discursive connections and disconnections reinforced in Put Your Best Face Forward Digital Literacy Resource

$\begin{array}{ll}\text { Online } & \text { Offline } \\ \text { Inauthentic } & \text { Authentic } \\ \text { Curated, Photoshopped, edited } & \text { "Real" } \\ \text { Photographed, textual, an image, a } & \text { In the flesh } \\ \text { performance } & \\ & \end{array}$

The discursive links and disconnections, as well as the significance and meaning making, align with the concept of digital dualism (Jurgenson, 2011) - the idea that the online self is different and inauthentic from the offline, in the flesh self.

New Materialist Analysis and Learning Resource Suggestions

The goal here is not to argue that selfies are not representations or presentations, but rather to argue that this is an incomplete picture of selfies. Left incomplete, this resource reinforces dualistic discourses regarding young people's experiences with both digital self-imaging and social media use. As such, I now move to suggest how new materialism might inject an important dimension in this learning resource and address the gap with regard to empirical work that connects embodiment and affect to mediated images online.

As mentioned, selfies are a multimodal digital literacy phenomenon. They are images produced via camera (representations); they are also often curated for different real and imagined audiences (Hogan, 2010; Abidin, 2016) (presentations); and, as reviewed in the literature review section and importantly for this next section, they are also a) materially influenced (Duguay, 2016; Rettberg, 2014; Wittkower, 2016) and b) affectively connected to the image makers (Coleman \& Ringrose, 2013; Raun, 2014; Warfield, 2016). How then do we incorporate the affective materiality of the image-maker as important components of a teaching resource? I've drafted out two pedagogical addenda to the lesson plan, based on my own empirical work and the work of material and affect theorists mentioned in the literature review. The first section is a series of question to be added onto one of the existing sections of the paper. The second is a stand-alone exercise.

\section{Amendment \#1 to Selfie-Awareness Section}

In the original section of the lesson plan, the teacher is guided to ask students to produce an image that is "selfie quality." The teacher is asked to publicly display an image of themselves, but this is an image to which the individual students lack an affective connection; moreover, they lack experiential knowledge of the process of the image's production. In alignment with contemporary research mentioned in the literature review, I suggest the inclusion of an activity that would encourage students to contemplate the material and affective dimensions of digital self-imaging. These might include reflecting on the space of image production, the body of the image producer, the technology used to 
produce the image, and the differences between the different cultures on the different social media platforms used for dissemination. For example:

Instructions: Ask students to take a picture they think is selfie-worthy. Give them time to do this on their own. They might go outside the class, find a place to take the image, and come back in 10 minutes. Ask them to consider the following questions:

\section{Place and Selfie-Awareness}

- In what location did you take an image?

- How did you feel in the places you chose to take an image?

- Where did you NOT take an image? Why not?

- How did you feel in the spaces you did not want to take an image?

- How do space and place affect your sense of privacy?

- On which social media platforms would you post your photos? Why those specific platforms?

- What sense of privacy and sense of security do you have on those platforms?

- On which social media platforms would you NOT post this image? Why not?

In this addendum section, I place an emphasis on emplacement (Hjorth \& Hendry, 2015; Hjorth \& Pink, 2012). I encourage students to think about how the materiality of spaces and places (both online and offline) encourages or discourages certain acts. In this discussion, we extend the critical thinking of agency to nonhuman actors instead of exclusively human or discursive actors-as proposed by theorists interested in materiality or new materialism. I push beyond representational frameworks that might reinforce digital dualism and the cleaving of online and offline spaces and experiences (Russell, 2012; Warfield, 2016b). I want to encourage students to think about offline spaces as working similarly to online spaces and notice how different audiences exist in both these spaces who may enable and disable expressions of self (Burgess, 2006).

In short, this series of questions both includes the empirical findings of contemporary research on selfies and encourages students to think about multimodal agency, the embodied experience of social media use, and the connections and similarities between online and offline spaces. Online and social media spaces thereby present experientially to many students not as flat walls on which flat, bodily, disconnected images are posted, but as spaces similar to physical rooms and places (Markham, 1998), in which images have an affective connection and are linked to and affect the experiences of other bodies (Warfield, 2016b). I suggest that this push toward embodiment and emplacement is the first step in rethinking Put Your Best Face Forward — or any digital literacy resourceto include contemporary empirical research on socially mediated self-imaging.

\section{Addendum \#2 Material-discursive genealogy of the Technology}

In this next section, I encourage students to expand their critical thinking to include the agency of other nonhuman actors, particularly that of the cellphone. I propose the following as discussion questions:

- When you look for a good angle, do you adopt poses from magazines?

- What is a cellphone in this moment of use? Is it a camera, or a stage, or a mirror? 
- What do cameras ask men/women/trans people to be in front of them? How do we negotiate our gender identity and expression with the cameraphone as imaging technology?

- What do filters do to your face to make it look good?

As mentioned in the literature review, I draw on the work of Huhtamo and Parikka (2011), Don Ihde (2012), and other media archaeology and postphenomenological scholars to suggest that students think about the genealogies of technologies since contemporary technologies, like the cellphone, are often compilations older technologies like a phone, tablet or gaming console. Our habitual use of those old technologies influence how we interact with new ones. Furthermore, I ask students to think about new technologies not as passive entities and media, but rather as agentic, discursively-laden, and involved elements that shape how we present ourselves online (Latour, 1979). This line of questions encourages an at once discursive and material approach to literacy — as well as a modality that articulates social media use and digital literacy as complex, multi-faceted, and entangled among human and nonhuman agents.

\section{Discussion and Implications}

This paper began by revealing the gap between Canadian digital literacy resources and contemporary empirical work on digital self-imaging practices by youth on social media. An overview of this literature reveals that selfies, and, broadly, digital images of the body shared on social media, are at once representations and presentations as well as materially and affectively entangled phenomena. Through a discourse analysis of the digital literacy resource, Put Your Best Face Forward, I illustrate that although empirical work by selfie scholars expose selfies to be materially and affectively embodied, Canadian digital literacy resources continue to present selfies often as representations (that is, photos distinct from the image-maker) or curated and theatrical performances (that are, in effect, separate from inauthentic versions of a more "real," authentic offline self).

Given these limitations, I suggest drawing on various theorists from the emerging tradition of new materialism and affect theory to imbue the lesson with more critical insight into materiality, the impact of nonhuman agency, and the important role of the body and affect in the production and sharing of images of the body online. The series of addenda I affix to the teaching resource produced by MediaSmarts encourage students to develop a more complex understanding of images of the body shared on social media - an understanding that could in turn offer an approach to social media self-images that recognizes the connection between images and living, affective, and feeling bodies.

This paper does not suggest that selfies are not representational or presentational, but rather that selfies are these and more. Importantly, digital self-imaging also has affective, embodied, and material dimensions, which I argue are necessary considerations for lesson plans and of particular importance to the Canadian context, where emerging laws and educational curricula address the sharing of intimate images online. Situating this work within the affective and material traditions of social media theory, I hope to contribute to these fields in ways similar to the work of scholars Jessica Ringrose, Hilevi Lenz Taguchi and other feminist new materialist scholars in education (PheMaterialists).

I argue for educational resources that are derived from the actual lived experiences of young people; for educational resources that move beyond representationalism and 
discursive traditions embedded in the self-imaging practices of the analogue age. I support the production of literacy resources that encourage young people to think about the material dimensions of taking and sharing images online; specifically, the entangled ways online and offline spaces work with dispersed networks of audiences, technologies and social media platforms, and the affective body. I also argue for the validation of young people's affective and bodily connection to images in the digital imaging process.

Much work has been done on the experiences of sharing personal images of the body on social media, but more needs to be done on the sharing of other people's images of the body on social media. Learning resources that acknowledge the affective dimensions of self-imaging practices could influence student attitudes toward the sharing and redistribution of images of others on social media (e.g., in the case of sexting and/or cyberbullying). Through an embodied and affective conceptualization of social media selfimaging — as opposed to a body-shaming approach — the felt body and the material forces of the technologies of image sharing are seen as agents in the production of the body online. In this moment, as material theorist Karen Barad would argue, affect and matter come to matter. An approach that defines selfies at once as representation, presentation, and as embodied encourages young people and educators to discuss the complex, entangled forces involved in the quotidian production and distribution of mediated selves on social media.

\section{References}

Abidin, C. (2016). Aren't these just young, rich women doing vain things online? Influences selfies as subversive frivolity. Social Media + Society, April-June, 117.

Althusser, L. (1970). On the Reproduction of Capitalism: Ideology and Ideological State Apparatuses. London: Verso.

Ash, J. (2015) Sensation, Networks and the GIF: Towards and allotropic account of affect. In Hillis, K., Paasonen, S., \& Petit, M. (2015). Networked affect. Cambridge, MA: MIT Press.

Barad, K. (2007). Meeting the universe halfway: Quantum physics and the entanglement of matter and meaning (2nd ed.). Durham, NC: Duke University Press.

Barthes, R. (1981). Camera lucida. New York, NY: The Noonday Press.

Bill C-13. (2015. Retrieved from https://openparliament.ca/bills/41-2/C-13/

Blackman, L. (2012). Immaterial bodies. Los Angeles, CalifCA. [u.a.]: Sage.

Bornstein, K. (1995). Gender outlaw: On men, women and the rest of us (1st ed.). New York, NY: Knopf Doubleday Publishing Group.

Bourdieu, P. (1979). Distinction: a social critique of the judgment of taste. Cambridge, MA: Harvard University Press.

Bourdieu, P., \& Wacquant, L. D. J. (1992). An invitation to reflexive sociology. Chicago, IL: University of Chicago Press.

Boyd, D. (2014). It's complicated: the social lives of networked teens. New Haven, CN: Yale University Press.

Braidotti, R. (2013). The posthuman. Oxford, UK: Polity Press.

Burgess, J. E. (2007). Vernacular creativity and new media. PhD thesis, Queensland University of Technology. 
Burns, A. (2015). Selfies self(ie)-discipline: Social regulation as enacted through the discussion of photographic practice. International Journal of Communications, 9, 1716-1763.

Butler, J. (1993). Bodies that matter: On the discursive limits of sex. New York, NY: Taylor \& Francis.

Cho, A. (2015). Queer Reverb: Tumblr, Affect, Time. In Hillis, K., Paasonen, S., \& Petit, M. (2015). Networked affect. Cambridge, MA: MIT Press.

Coleman, R. and Ringrose, J. (2013) Looking and Desiring Machines: a Deleuzian mapping of bodies and affect. Rebecca Coleman \& Jessica Ringrose (eds.), Deleuze and Research Methodologies. Edinburgh University Press. pp. 125.

Deleuze, G. \& Guattari, F. (1987). Thousand Plateaus: capitalism and schizophrenia. Minneapolis, MN: University of Minnesota Press.

Doan, P. (2010). The tyranny of gendered spaces - reflections from beyond the gender dichotomy. Gender, Place \& Culture, 17(5), 635-654.

http://dx.doi.org/10.1080/0966369x.2010.503121

Duguay, S. (2016). Dressing up Tinderella: Interrogating authenticity claims on the mobile dating app Tinder. Information, Communication \& Society, 20(3), 351367. http://dx.doi.org/10.1080/1369118x.2016.1168471

Fairclough, N. (1989). Language and power (2nd ed.). New York, NY: Longman.

Fairclough, N. (2010). Critical discourse analysis: The critical study of language (2nd ed.). Harlow, England: Longman Publishing Group.

Foucault, M. (1972). The archaeology of knowledge \& the discourse on language. New York, NY: Pantheon Books.

Gee, J. (1999). An introduction to discourse analysis: Theory and method. New York, NY: Routledge.

Goffman, E. (1956). The presentation of self in everyday life. New York: NY: Penguin Random House.

Gye, L. (2009). Picture this: The impact of mobile camera phones on personal photographic practices. Continuum, 21(2), 279-288.

Hillis, K., Paasonen, S., \& Petit, M. (2015). Networked affect. Cambridge, MA: MIT Press.

Hjorth, L., \& Hendry, N. (2015). A snapshot of social media: Camera phone practices. Social Media + Society, 1, 1-3.

Hjorth, L., \& Pink, S. (2012). Emplaced cartographies: Reconceptualising camera phone. Media International Australia. 145 (1), p.145-155.

Hogan, B. (2010). The presentation of self in the age of social media: Distinguishing performances and exhibitions online. Bulletin of Science, Technology \& Society, 30(6), 377-386. http://dx.doi.org/10.1177/0270467610385893

Huhtamo, E. and Parikka, J. (2011). Media Archaeology: approaches, applications, and implications. Oakland, CA: University of California Press.

Ihde, D. (2012). Experimental phenomenology: Multistabilities (2nd ed.). Albany, NY: State University of New York Press.

Jurgenson, N. (2011). Digital dualism and the fallacy of web objectivity. Retrieved from http://thesocietypages.org/cyborgology/2011/09/13/digital-dualism-and-thefallacy-of-web-objectivity/ 
Kindberg, T., Spasojevic, M., Fleck, R., \& Sellen, A. (2005). The ubiquitous camera: An in-depth study of camera phone use. IEEE Pervasive Computing, 4(2), 42-50. http://dx.doi.org/10.1109/mprv.2005.42

Kirschenbaum, M. (2008). Mechanisms: New media and the forensic imagination. Cambridge, MA: MIT Press.

Latour, B. (1979). We have never been modern (5th ed.). New York, NY: Harvester Wheatsheaf.

Livingstone, S. (2009). Children and the Internet. Cambirdge, UK: Polity Press.

Maddison, S. (2015). “Make Love Not Porn”: Entrepreneurial Voyeurism, Agency, and Affect. In Networked Affect, 151.

Markham, A. (1998). Life online. Walnut Creek, CA: Altamira Press.

Massumi, B. (2015). Politics of Affect. Cambridge, UK: Polity Press.

McVeigh-Schultz, J., \& Baym, N. (2015). Thinking of you: Vernacular affordance in the context of the microsocial relationship app, couple. Social Media + Society, 1(2), 1-13. http://dx.doi.org/10.1177/2056305115604649

MediaSmarts. (2016). Put your best face forward. Retrieved from http://mediasmarts.ca/teacher-resources/put-your-best-face-forward

Miltner, K., \& Baym, N. (2015). The selfie of the year of the selfie: Reflections on a media scandal. International Journal of Communication, 9, 1701-1715.

Okabe, D. \& Ito, M. (2006). Everyday Contexts of Camera Phone Use: Steps Toward Technosocial Ethnographic Frameworks. In Höflich, J. \& Hartmann, M. Eds. Mobile Communication in Everyday Life: An Ethnographic View. Berlin: Frank \& Timme

Papacharissi, Z. (2010). A Networked self: Identity, community, and culture on social network sites. London, UK: Taylor \& Francis.

Raun, T. (2014). Out Online: Trans self-represenation and community building on Youtube (gender, bodies, and transformation). New York: Routledge.

Rettberg, J. (2014). Seeing ourselves through technology. Basingstoke, UK: Palgrave Macmillan.

Reichert, R., \& Richterich, A. (2015). Introduction: Digital Materialism. Digital Culture and Society. Vol 1(1), p.5-20.

Ringrose, J. (2015). Selfies, Reflies, and phallic tagging: posthuman participation in teen digital sexual assemblages. Educational Philsophy and Theory. 49:11, 10661079, DOI: $10.1080 / 00131857.2016 .1185686$

Russell, L. (2012). Glitch Feminism. Retrieved from: https://thesocietypages.org/cyborgology/2012/12/10/digital-dualism-and-theglitch-feminism-manifesto/

Schwartz, R., \& Halegoua, G. (2014). The spatial self: Location-based identity performance on social media. New Media \& Society, 17(10), 1643-1660. http://dx.doi.org/10.1177/1461444814531364

Scifo, B. (2009). The sociocultural forms of mobile personal photographs in a crossmedia ecology: Reflections starting from the young Italian experience.Knowledge, Technology \& Policy, 22(3), 185-194. http://dx.doi.org/10.1007/s12130-0099080-1

Senft, T., \& Baym, N. (2015). What does the selfie say? Investigating a global phenomenon. International Journal of Communications, 9, 1588-1606. 
Sontag, S. (2008). On Photography. London, UK: Picador.

Sundén, J. (2015). On trans-, glitch, and gender as machinery of failure. First Monday. 20(4-5).

Taguchi, H. L. (2011). Investigating learning, participation and becoming in early childhood practices with a relational Materialist approach. Global Studies of Childhood, 1(1). http://dx.doi.org/10.2304/gsch.2011.1.1.36

Tiidenberg, K. (2018). Selfies: why we love and hate them. Bingley, UK: Emerald Publishing Limited.

Urry, J. (2002). The Tourist Gaze. London, UK: Sage Publications.

van Dijk, T. (2008). Discourse and power. Basingstoke, UK: Palgrave Macmillan.

Warfield, K. (2015). The Model, the \#realme, and the self-conscious thespian. Digital subjectivities in the selfie. International Journal on The Image, 6(2), 1-16.

Warfield, K. (2016a). "Reblogging someone's selfie is seen as a really nice thing to do": spatiality and emplacement within a non-dominant platform vernacular on

Tumblr. International Journal of Communication.

Warfield, K. (2016b). Making the cut: An agential realism examination of selfies and touch. Social Media + Society, April-June.

Warfield, K., Cambre, C., \& Abidin, C. (2016). Introduction to the Social Media + Society Special Issue on Selfies: Me-diated Inter-faces. Social Media + Society, 2(2), 1-5. http://dx.doi.org/10.1177/2056305116641344

Wittkower, D. E. (2016). Principles of anti-discriminatory design. Paper presented at the 2016 IEEE International Symposium on Ethics in Engineering, Science and Technology 